J. Environ. Sci.

Institute of Environmental Studies and Research - Ain Shams University

\title{
ASSESSMENT OF SOME BACTERIOLOGICAL AND PHYSICOCHEMICAL PROPERTIES OF GROUNDWATER IN AL KUFRA AREA, LIBYA
}

\author{
Hafez S. Saleh ${ }^{(1)}$; Mohamed G. El-Malky ${ }^{(1)}$; Noha S. Donia ${ }^{(1)}$ \\ and Frhat, M. S. Bo Aiad ${ }^{(2)}$
}

1) Institute of environmental studies \& Research, Ain-Shams University

2) Faculty of Arts And Science, Benghazi University, LIBYA

\begin{abstract}
Water is valuable natural resources and plays vital role to sustain the international economy. The scarcity and pollution of ground water has become serious problem in the arid zones which should be addressed. This study was carried out to assess the quality of ground water for the human consumption in the rural and urban areas of Al Kufra area, Libya which lacked sanitation services, resulting in the use of black wells and sometimesold water wells as sewage drains. It is possible to access sewage water to the ground water with many contaminants, causing contamination of groundwater in this area. Ten ground water samples were collected from 10 wells in AlKufra during 2016. The bacteriological and physicochemical parameters such as $\mathrm{pH}$, Electrical conductivity (EC) and Total dissolved solids (TDS). Calcium (Ca), Magnesium (Mg), Sodium (Na), Potassium (K), Chloride (Cl), Sulfate (SO4), Bicarbonate (HCO3), Nitrate (NO3), copper $(\mathrm{Cu})$ and iron $(\mathrm{Fe})$ were analyzed using standard procedures. The results were compared with WHO and Libyan water standards. In this study, the most of the parameters of the water samples were below the permissible limits and suitable for drinking purposes except some parameters in some wells.

Keywords: Bacteriological; Physicochemical; Assessment; Groundwater; Al Kufra Area, Libya
\end{abstract}




\section{INTRODUCTION}

The state of Libya is among the world's most water scare area it has been responded to specialized water institutions, with extensive investments in water infrastructures including ground water sources, dams, the Great Man Made River Project (GMMRP), and desalination plants (Abufayed and Elkebir, 2010). Municipal water demand has increased markedly in the last 4 decades in response to high population growth rates and increased per capita requirements. Based on this fact the chemical and microbiological studies have been highly recommended for drinking water quality (Wright et al, 2004).

The demand for fresh water has increased significantly in Libya, due to the population growth rate, consequently, the public water supply has increased markedly, either in Urban area or rural town (Hosan et al., 2011; Salem and Alshergawi, 2013). Even though, it has been concluded that drinking water in urban and town area have no hazardous effects on human health. The analysis of water quality parameters must be identical or in the allowed international and national recognized specifications within the maximum permissible limit of WHO (WHO, 1996) and Libyan standards (LNCSS, 1992).

Groundwater is the main source of water in Libya, providing about $97 \%$ of the amount of water used in Libya in all industrial and agricultural activities and household uses (Shahin, 2003). The water is found in underground basins in south-eastern Libya (Kufra and Sarir) and in southwest Libya (Mourzk). As a result of the existence of Libya within the arid and semi-arid regions due to extreme climatic conditions and lack of rain where 
the annual rainfall is less than $100 \mathrm{~mm}$ annually and average annual evaporation up to $6.8 \mathrm{~mm} /$ day, which is $2500 \mathrm{~mm} /$ year. It is much higher than the average rainfall, and has a significant role in increasing pressure on groundwater. The consumption of agriculture is $80 \%$ of the total water resources. The amount of groundwater that can be withdrawn currently overages 4500 million cubic meters per year (Great Man-Made River). As a result of the increase in population, agricultural and industrial expansion, and in the absence of the sustainable management of available water resources, the withdrawal of groundwater has increased over the past years, resulting in a decrease in groundwater levels and an increase in the quantity of wastewater which is considered one of the main problems of groundwater pollution in Libya. Due to the failure of the state to build sewage plants and networks in the areas of groundwater basins, especially in the Kufra basin and the bed in the south-east and the basin of Moursq in the south-west, sewage has become a threat to contamination of groundwater in Libya.

The present study has conducting some of estimation bacteriological and physico-chemical analysis parameters, and aimed to monitor the ground water quality of drilling wells in Al-Kufra area which located in south east part of Libya.

\section{MATERIALS AND METHODS}

Location of Study Area: The State of Libya is located in North Africa on the southern coast of the Mediterranean Sea bordered to the east by Egypt, to the south-east by Sudan, to the south by Chad and Niger, to the west by Algeria and from the north-west by Tunisia and by Libya to an area of $1.759 .540 \mathrm{~km} 2$ 
making it 17th in the world. Libya located (Fig.1) between latitudes $34^{\circ}$ degrees and $19^{\circ}$ degrees north, and longitudes $26^{\circ}$ degrees and $9^{\circ}$ degrees east. The coast of Libya is the longest coast in the Mediterranean countries of Africa with the length of $1,770 \mathrm{~km}$. The climate in most of the country is dry between desert and semi-desert, except for the northern regions that have a mild climate of the Mediterranean region. The Desert, which covers much of Libya, is one of the most arid places on earth. In some places, years may pass without precipitation, and even rain in the southern highlands is rare, once every 5-10 years in the oases of southeastern Libya.

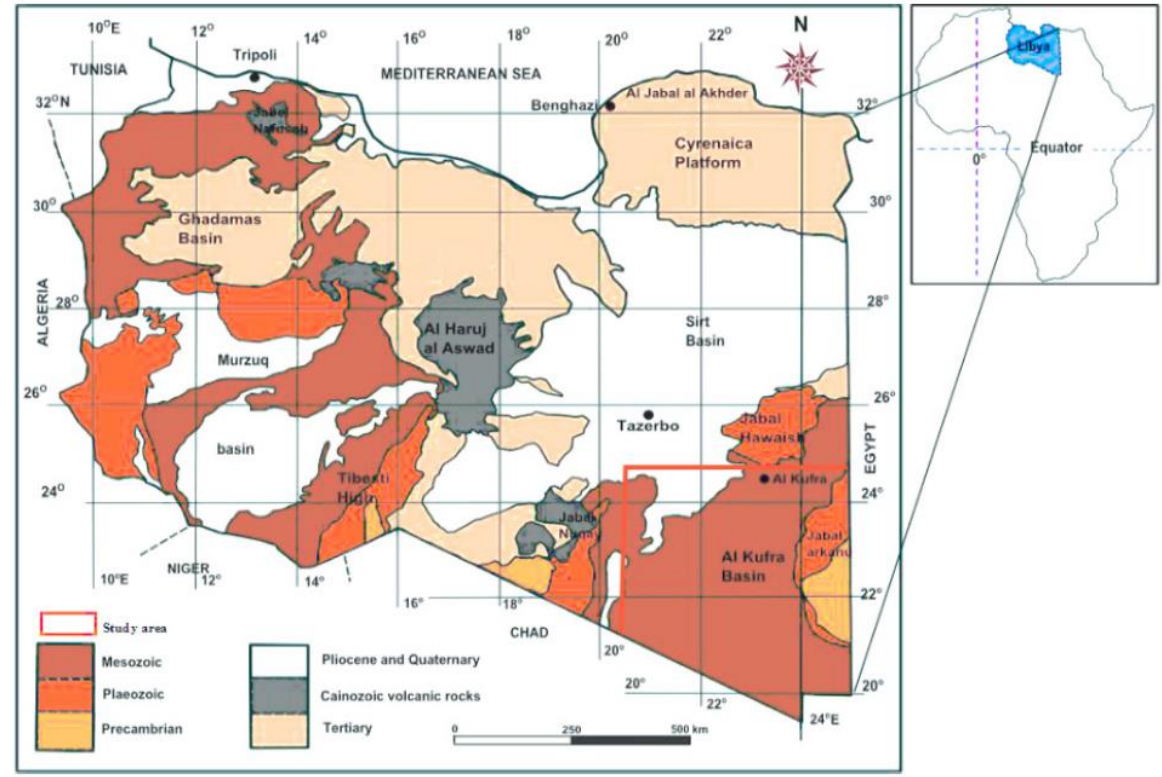

Fig.(1): Location Map

The study area is located in the southeastern corner of Libya, as in the map. It occupies $27 \%$ of the area of Libya, located between the districts of (24 North and 19.8) and long lines (24.4 East and 18.7E). It is about $1000 \mathrm{~km}$ south of the second largest city of Libya Benghazi, the study area is estimated 4 
J. Environ. Sci.

Institute of Environmental Studies and Research - Ain Shams University

at 483510 square kilometers (Bureau of Information and Documentation) and thus occupies the first ranking in terms of area in Libya (Fig.2)

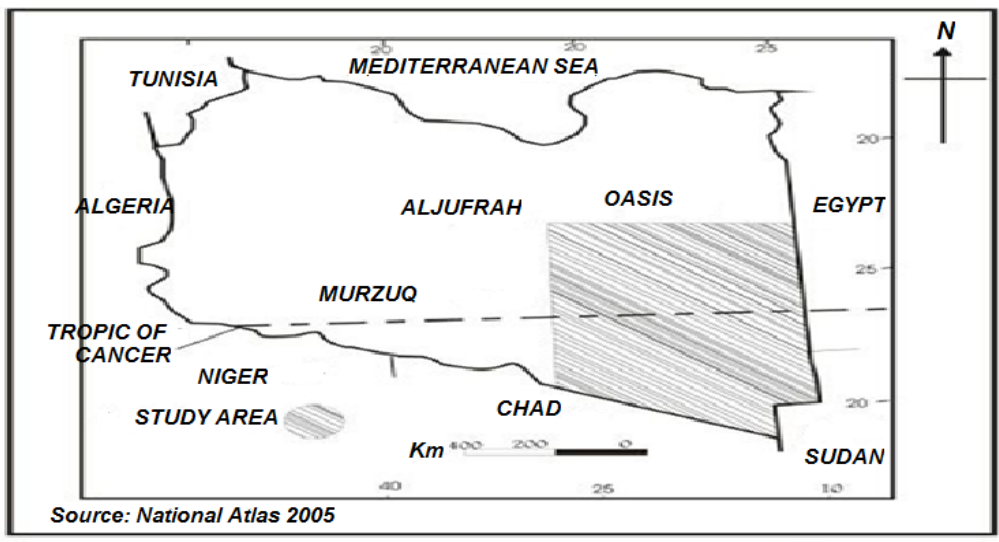

Fig.(2): Map of Al Kufra (study area)

The groundwater samples were collected from ten wells in Al-Kufra area which showed in the (Fig.2). Their names, elevations, types of soil, locality of wells, depth of wells are given in Table (1). The groundwater samples were collected three times in March, June and November 2016 from 10 wells of Al-Kufra area. 
Table (1): Information on the wells of Al-Kufra Area.

\begin{tabular}{|c|c|c|c|c|c|}
\hline \multirow{2}{*}{$\begin{array}{l}\text { Well } \\
\text { No }\end{array}$} & \multirow{2}{*}{$\begin{array}{l}\text { height above } \\
\text { sea level, } \mathrm{m}\end{array}$} & \multirow{2}{*}{ Rock type } & \multirow{2}{*}{ Depth, m } & \multicolumn{2}{|c|}{ Location coordinates } \\
\hline & & & & East & North \\
\hline "W01 & $\overline{372}$ & Limestone & 300 & $\begin{array}{lll}23 & 17 & 49\end{array}$ & $\begin{array}{lll}24 & 13 & 11\end{array}$ \\
\hline W02 & 370 & Limestone & 200 & $\begin{array}{lll}23 & 17 & 41\end{array}$ & $24 \quad 1306$ \\
\hline W03 & 369 & Limestone & 250 & $\begin{array}{lll}23 & 18 & 31\end{array}$ & $24 \quad 1300$ \\
\hline W04 & 383 & Limestone & 200 & $\begin{array}{lll}23 & 18 & 01\end{array}$ & $24 \quad 1151$ \\
\hline W05 & 382 & Limestone & 300 & $\begin{array}{lll}23 & 17 & 07\end{array}$ & $24 \quad 11 \quad 35$ \\
\hline W06 & 373 & Marl, clay, limestone & 300 & $\begin{array}{lll}23 & 17 & 38 \\
\end{array}$ & $24 \quad 10 \quad 13$ \\
\hline W07 & 382 & Limestone & 250 & $\begin{array}{lll}23 & 17 & 48 \\
\end{array}$ & $24 \quad 13 \quad 21$ \\
\hline W08 & 370 & limestone, shale, clay & 300 & $\begin{array}{lll}23 & 19 & 50\end{array}$ & $24 \quad 11 \quad 10$ \\
\hline W09 & 387 & limestone, shale, clay & 300 & $\begin{array}{lll}23 & 14 & 19\end{array}$ & 240736 \\
\hline W10 & 376 & limestone, shale, clay & 50 & $\begin{array}{lll}23 & 17 & 39\end{array}$ & $24 \quad 13 \quad 02$ \\
\hline
\end{tabular}

Physical and Chemical Analysis: The temperature of the samples was measured in the field itself at the time of sample collection using mercury thermometer. Also, Measurements of physical unstable parameters such as $\mathrm{pH}$ and electrical conductivity (EC) were conducted in the field with portable $\mathrm{pH}-$ meter (Ino lab WTW) equipped with glass combined electrode $(\mathrm{pH}-$ electrode sen Tix 61-B023009AP017) and microprocessor electrical conductive meter (WTW Multi 340i with WTW Tera Con 325 conductive cell) which were calibrated prior to taking of readings. The chemical analysis were conducted using standard procedures recommended by American Public Health Association (APHA 1998). Total dissolved solid was determined by gravimetric method and calcium and magnesium were determined by EDTA titrimetric method. Chloride ion was determined by silver nitrate titration. Analysis of sodium and potassium ions were carried out using a flame photometer (PFP7Flame Photometer, Jenway, Germany). The toxic heavy metals that affect the health (such as copper, and iron) were determined using Atomic Absorption Spectrophotometer (Flame Atomic Absorption GBC 
Scientific Equipment SAVANTAA). Dissolved oxygen (azide modified winkler), Nitrate (cadmium reduction), Chloride (Sliver nitrate titration), Sulphate (Turbid metric Method) and Bicarbonate (Titration with $\mathrm{HCl}$ and methyl orange indicator).

Bacteriological Analysis of Groundwater Samples: Sterile $250 \mathrm{ml}$ bottle was used for sample collection. Carefully unscrew the cap and immediately hold the bottle under the water surface of the wells and fill. Membrane filters (MF) method described by (Noble, et al., 2003) was strictly followed; 100 mls of each water sample was filtered through sterile membrane which retained the bacteria on its surface. The membrane was removed aseptically and placed on a MacConkey medium that was then incubated at $37^{\circ} \mathrm{C}$ for 24 hrs. Coliform colonies (indicating faecal contamination) growing on the surface of the membrane were counted and recorded as Coliform density (total Coliform colonies per $100 \mathrm{~mL}$ ) or colony forming unit (CFU).

\section{RESULTS AND DISCUSSION}

In this study, some physical, chemical parameters and bacteriological analysis, for 10 samples from groundwater wells in Al-Kufra area, were carried out to verify the suitability of the wells water for human consumption. The physical and chemical parameters of the water samples were estimated in ten water wells in Al-Kufra area, along with the average value and standard deviation of each parameter. (Tables 2, 3 and 4). Table (5) shows the bacterial results of groundwater samples in ten wells. 
Table (2): Descriptive statistics of chemical analysis (cations and heavy metals, mg/L) of Al-Kufra area.

\begin{tabular}{|c|c|c|c|c|c|c|c|}
\hline "Well & & $\mathbf{M g}^{++}$ & 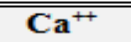 & 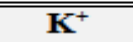 & $\mathbf{N a}^{+}$ & Fe(II) & Cu(II) \\
\hline \multirow[t]{2}{*}{ W01 } & Average & 12.56 & 110.00 & 6.00 & 455.00 & 0.01 & 0.17 \\
\hline & STD & 0.0081 & 0.8164 & 0.4082 & 4.0824 & 0.0008 & 0.00081 \\
\hline \multirow[t]{2}{*}{ W02 } & Average & 13.87 & 140.00 & 6.90 & 44.00 & 0.02 & 0.17 \\
\hline & STD & 0.0163 & 0.2449 & 0.0816 & 1.6329 & 0.0016 & 0.00163 \\
\hline \multirow[t]{2}{*}{ W03 } & Average & 6.84 & 66.00 & 4.20 & 12.50 & 0.02 & 0.14 \\
\hline & STD & 0.0081 & 0.4082 & 0.0816 & 0.1632 & 0.0016 & 0.00326 \\
\hline \multirow[t]{2}{*}{ W04 } & Average & 25.87 & 140.00 & 14.90 & 150.00 & 0.02 & 0.21 \\
\hline & STD & 0.1061 & 1.6329 & 0.4898 & 1.6329 & 0.0024 & 0.0008 \\
\hline \multirow[t]{2}{*}{ W05 } & Average & 8.62 & 80.00 & 5.40 & 20.00 & 0.01 & 0.25 \\
\hline & STD & 0.3102 & 1.6329 & 0.3265 & 0.8164 & 0.0016 & 0.01061 \\
\hline \multirow[t]{2}{*}{ W06 } & Average & 9.00 & 58.00 & 7.00 & 51.40 & 0.06 & 0.19 \\
\hline & STD & 1.6329 & 0.8164 & 0.8164 & 1.1430 & 0.0081 & 0.00489 \\
\hline \multirow[t]{2}{*}{ W07 } & Average & 9.00 & 28.50 & 5.30 & 41.00 & 0.12 & 0.13 \\
\hline & STD & 4.8989 & 0.4082 & 0.1632 & 3.2659 & 0.0081 & 0.00408 \\
\hline \multirow[t]{2}{*}{ Wos } & Average & 12.00 & 35.00 & 10.00 & 86.00 & 0.05 & 0.19 \\
\hline & STD & 1.6329 & 4.0824 & 0.8164 & 4.8989 & 0.0244 & 0.00816 \\
\hline \multirow[t]{2}{*}{ W09 } & Average & 5.90 & 16.00 & 5.30 & 25.00 & 0.17 & 0.12 \\
\hline & STD & 0.4898 & 1.6329 & 1.8779 & 1.6329 & 0.0489 & 0.01224 \\
\hline \multirow[t]{3}{*}{ W10 } & Average & 41.00 & 430.00 & 11.00 & 130.00 & 0.15 & 0.25 \\
\hline & STD & 1.6329 & 8.1649 & 1.6329 & 8.1649 & 0.0081 & 0.03755 \\
\hline & LSS & 150 & 200 & 40.00 & 200 & 0.30 & 1.0 \\
\hline \multicolumn{2}{|c|}{ WHO } & 50 & 200 & 20.00 & 200 & 0.30 & 1.0 \\
\hline
\end{tabular}

All parameters are expressed in mg/L; STD: standard deviation

The copper values for all samples are within the safe limits of WHO (1.0 $\mathrm{mg} / \mathrm{L}$ ). Large amounts of sodium give a salty taste when combined with chloride. Moderate amounts have a simple effect on water utility in most purposes. Sodium concentrations range from 12.5 to $130 \mathrm{mg} / \mathrm{L}$ (wells $r$ and 7). It is located under WHO safe limits (200 mg/L) while in wells (4 and 10) 
sodium concentrations are 150 and 130 respectively. It is considered to be close to the proportions not allowed in Libyan standards and WHO.

The main sources of iron in groundwater are of course the rocks that make up minerals and in all wells between 0.01 to $0.17 \mathrm{mg} / \mathrm{L}$ and are among the allowable ratios where the ratio is 0.3 (Table 2) under WHO guidelines.

The results in Table (2) indicate a variable concentration of calcium from 16 to $430 \mathrm{mg} / \mathrm{L}$ where the ratios in well $(2,4)$ are high. They reached 140 $\mathrm{mg} / \mathrm{L}$ while the allowed ratio in well (10) reached $430 \mathrm{mg} / \mathrm{L}$ and the allowed rate is $200 \mathrm{mg} / \mathrm{L}$. Magnesium is supposed to be non-toxic at natural concentration in natural water. All samples are found within the normal tolerances.

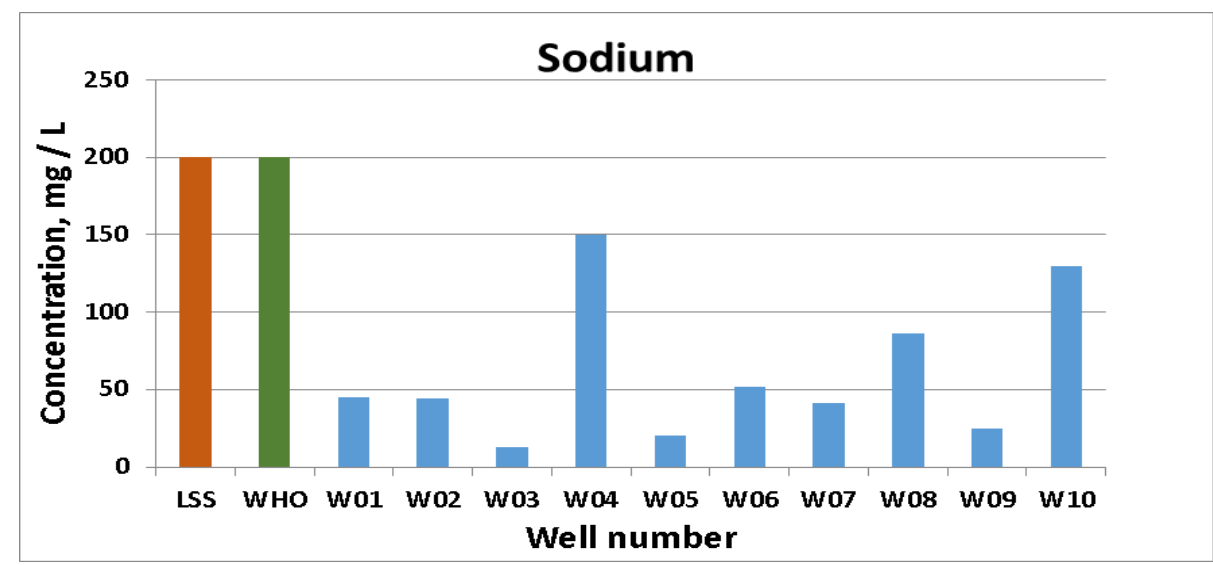

Fig. (3): Sodium concentrations (mg/L) in the studied wells compared with Libyan Standard and WHO. 


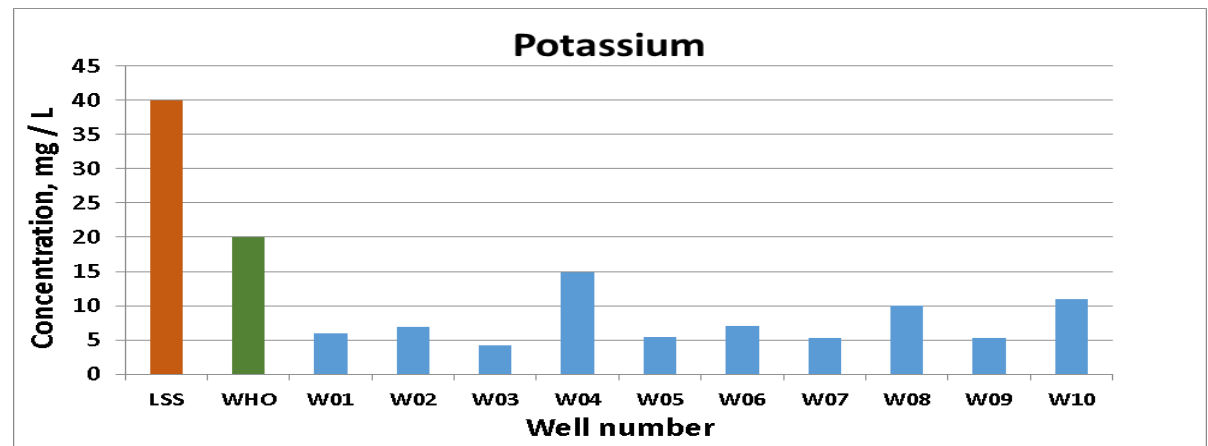

Fig. (4): Potassium concentrations $(\mathrm{mg} / \mathrm{L})$ in the studied wells compared with Libyan Standard and WHO.

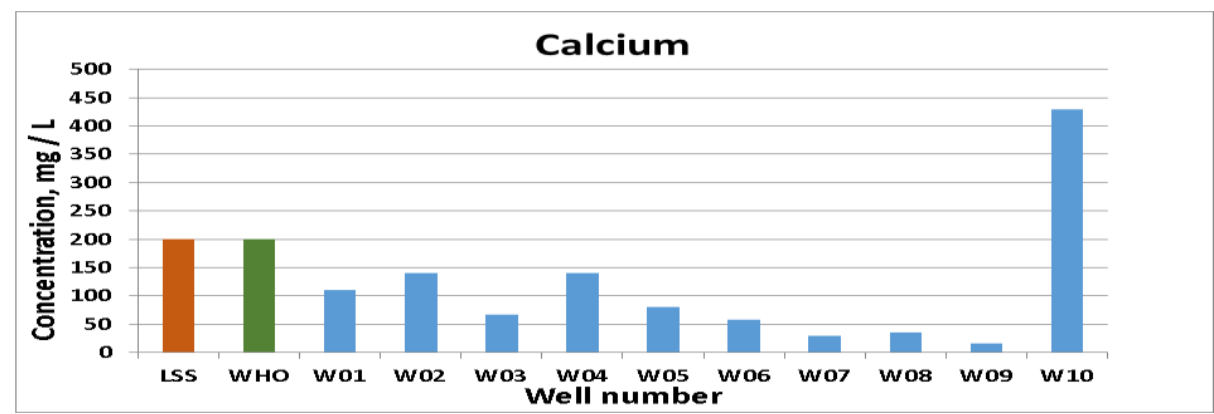

Fig. (5): Calcium concentrations in the studied wells compared with Libyan Standard and WHO.

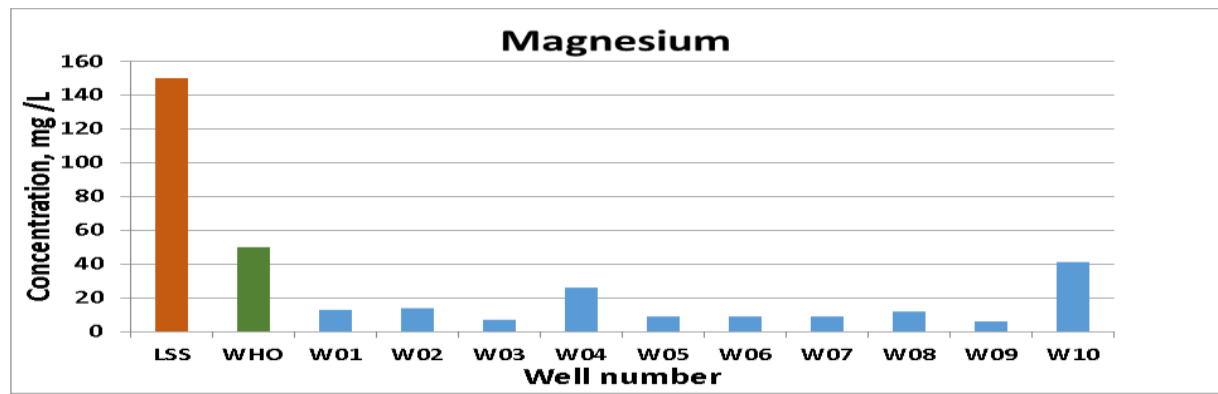

Fig. (6): Magnesium concentrations (mg/L) in the studied wells compared with Libyan Standard and WHO. 
J. Environ. Sci.

Institute of Environmental Studies and Research - Ain Shams University

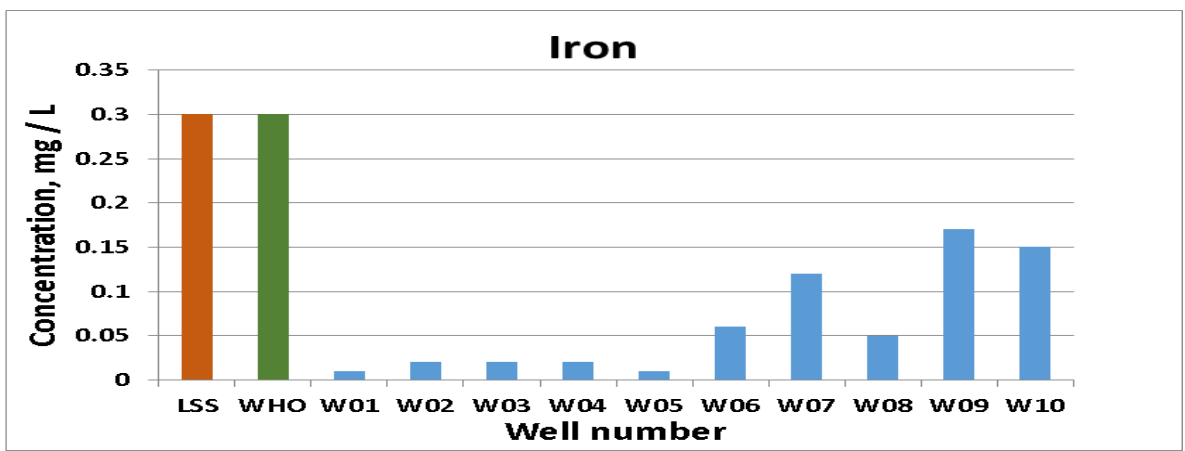

Fig. (7): Iron concentrations $(\mathrm{mg} / \mathrm{L})$ in the studied wells compared with Libyan Standard and WHO.

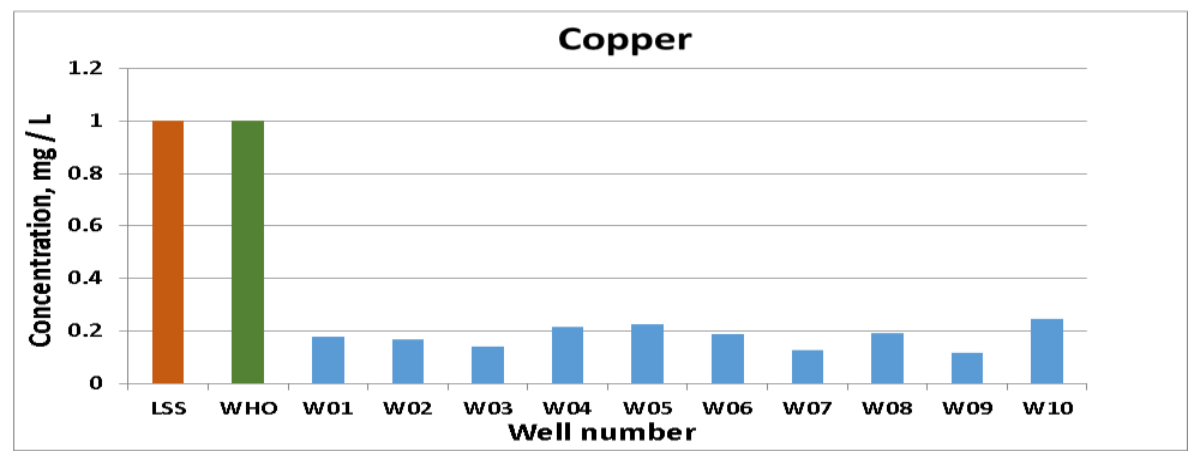

Fig. (8): Copper concentrations $(\mathrm{mg} / \mathrm{L})$ in the studied wells compared with Libyan Standard and WHO.

Table (3): shows the results of concentrations of anions in the groundwater of the studied wells. Bicarbonates varied from 36.6 to $123 \mathrm{mg} / \mathrm{L}$. Nitrates is within the limit of $50 \mathrm{mg} / \mathrm{L}$ recorded by (WHO, World Health Organization 1993). High nitrate values in groundwater may be due to organic pollution and wastewater. 
Table (3): Descriptive statistics of chemical analysis (anions, mg/L) of $\mathrm{Al}$ Kufra area.

\begin{tabular}{|c|c|c|c|c|c|}
\hline Well & & $\mathrm{HCO}_{3-}$ & $\mathrm{SO}_{4-}$ & Cl- & $\mathrm{NO}_{\mathbf{3}^{-}}$ \\
\hline \multirow[t]{2}{*}{$\overline{\text { W01 }}$} & Average & 61.00 & 53.50 & 93.00 & $>0.02$ \\
\hline & STD & 0.81649 & 0.24494 & 0.81649 & *** \\
\hline \multirow[t]{2}{*}{ W02 } & Average & 42.70 & 60.30 & 100.00 & $>0.02$ \\
\hline & STD & 0.16329 & 0.16329 & 1.63299 & *** \\
\hline \multirow[t]{2}{*}{ W03 } & Average & 42.70 & 40.00 & 28.60 & $>0.02$ \\
\hline & STD & 0.57154 & 1.3589 & 0.48989 & *** \\
\hline \multirow[t]{2}{*}{ W04 } & Average & 42.70 & 75.00 & 286.00 & $>0.02$ \\
\hline & STD & 0.57154 & 0.81659 & 2.4494 & $* *$ \\
\hline \multirow[t]{2}{*}{ W05 } & Average & 43.00 & 40.00 & 43.00 & $>0.02$ \\
\hline & STD & 0.081649 & 1.22474 & 2.4494 & *** \\
\hline \multirow[t]{2}{*}{ W06 } & Average & 42.70 & 62.00 & 113.00 & $>0.02$ \\
\hline & STD & 0.32659 & 1.63299 & 7.3484 & *** \\
\hline \multirow[t]{2}{*}{ W07 } & Average & 42.70 & 55.00 & 70.00 & $>0.02$ \\
\hline & STD & 0.16329 & 4.08248 & 4.0824 & $* *$ \\
\hline \multirow[t]{2}{*}{ W08 } & Average & 36.60 & 70.00 & 153.00 & $>0.02$ \\
\hline & STD & 0.24494 & 0.81649 & 0.40824 & *** \\
\hline \multirow[t]{2}{*}{ W09 } & Average & 42.70 & 40.00 & 39.50 & $>0.02$ \\
\hline & STD & 2.20454 & 1.22474 & 0.40824 & $* *$ \\
\hline \multirow[t]{2}{*}{ W10 } & Average & 123.00 & 213.00 & 250.00 & $>0.02$ \\
\hline & STD & 2.44948 & 6.53197 & 8.16496 & $* *$ \\
\hline \multicolumn{2}{|c|}{ LSS } & -ב-י & 400 & 250 & 45 \\
\hline \multicolumn{2}{|c|}{ WHO } & 200 & 250 & 250 & 50 \\
\hline
\end{tabular}

Chloride concentrations range from $28.6 \mathrm{mg} / \mathrm{L}$ to $286 \mathrm{mg} / \mathrm{L}$ in groundwater in the study area. Abundant chloride in groundwater can indicate leakage from certain types of sewage facilities. Human waste is usually high in chloride content. Once these wastes are deposited in the sewage lakes, chloride is often moved into the groundwater system and because it is not absorbed by the soil, chloride can travel large distances (Jha and Verma, 2000). Chloride occurs naturally in all types of water. Chloride is produced in 
natural water from agricultural and industrial activities and chloride-rich rocks. The high concentration of chloride is due to the invasion of household waste and the elimination of human activities (Jha and Verma, 2000). Chloride concentrations in wells ( $4 \& 10$ ) range between 286 and $250 \mathrm{mg} / \mathrm{L}$, which is more than the WHO limit (250 ppm), indicating that pollution is due to chloride, on the other hand, Chloride concentrations within the allowable rates in Libyan specifications and WHO. Sulphate concentrations range from 40 to $213 \mathrm{mg} / \mathrm{L}$ and are within the limits allowed by the World Health Organization $(250 \mathrm{mg} / \mathrm{L})$.

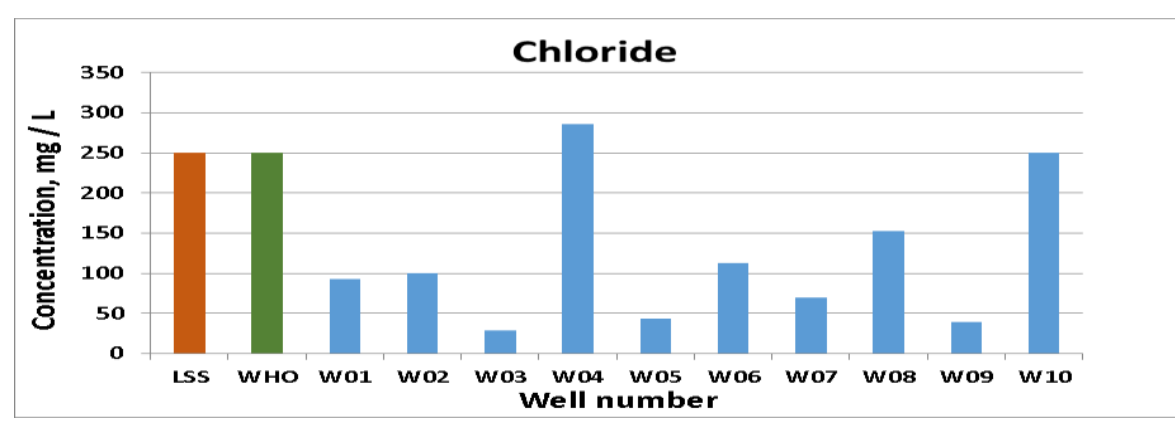

Fig. (9): Chloride concentrations (mg/L) in the studied wells compared with Libyan Standard and WHO.

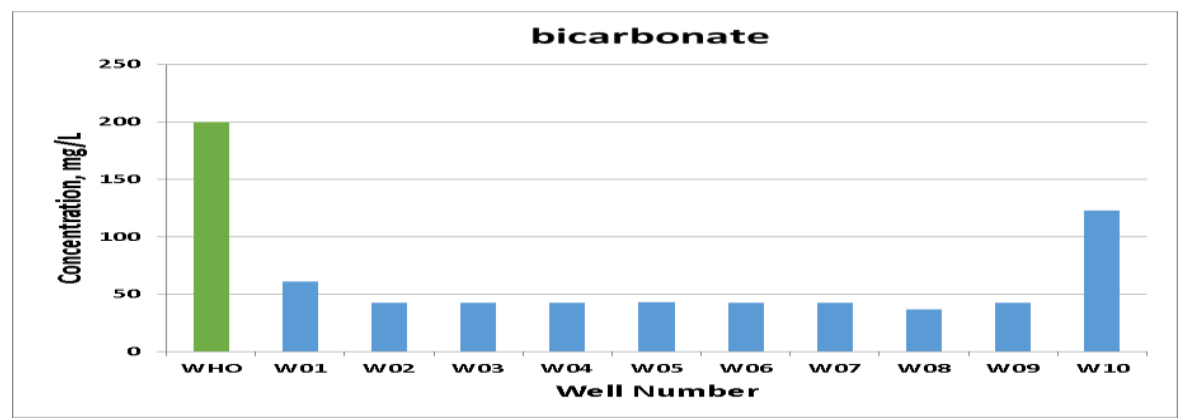

Fig. (10): Bicarbonate concentrations $(\mathrm{mg} / \mathrm{L})$ in the studied wells compared with Libyan Standard and WHO. 
Hafez S. Saleh, et al

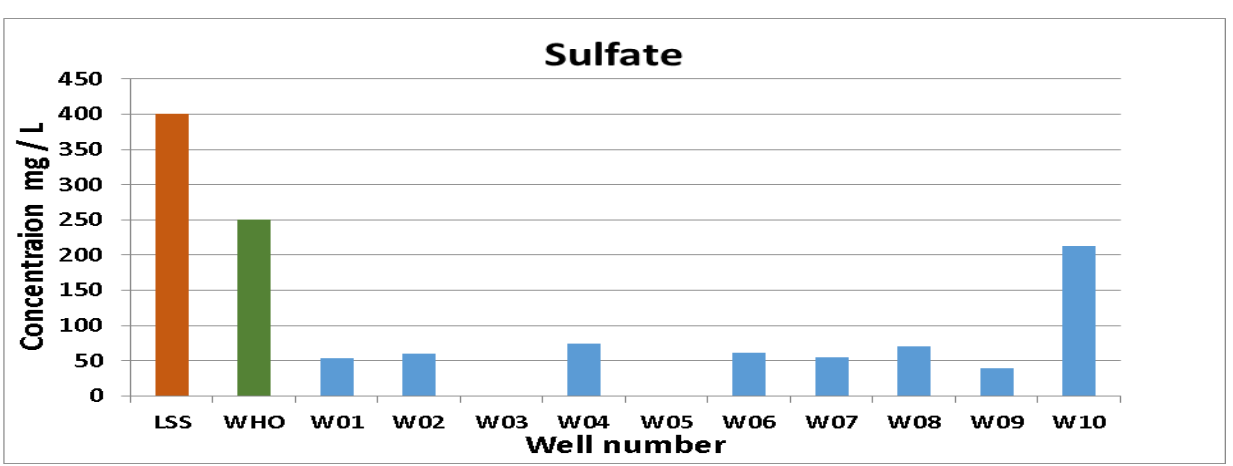

Fig. (11): Sulfate concentrations $(\mathrm{mg} / \mathrm{L})$ in the studied wells compared with Libyan Standard and WHO. 
J. Environ. Sci.

Institute of Environmental Studies and Research - Ain Shams University

Table (4): Descriptive statistics of physical parameters of Al-Kufra area.

\begin{tabular}{|c|c|c|c|c|c|c|}
\hline Wellax & $a$ & $\begin{array}{l}\text { TDS, } \\
\text { mg/La }\end{array}$ & pHo & $\mathbf{D O}, \cdot \mathbf{m g} / \mathrm{L} a$ & Temp., ${ }^{\circ} \mathrm{C} a$ & $\begin{array}{c}\mathrm{EC}, \cdot \\
\mu \mathrm{S} / \mathrm{cm} \sigma\end{array}$ \\
\hline W01a & Averager & $350 x$ & 6.10 & 6.80 & $29 x$ & $580 x$ \\
\hline$a$ & STD $a$ & 0.8164 & 0.0816 & $0.0816 x$ & 1.63290 & $12.247 \approx$ \\
\hline W02a & Averagex & $391 x$ & 6.10 & 7.30 & $29 x$ & 6520 \\
\hline$a$ & STD & 163290 & 0.1632 & $0.2449 x$ & $3.2659 x$ & 8.16490 \\
\hline W03a & Average $x$ & 2050 & $5.9 x$ & 8.30 & $28 x$ & 3420 \\
\hline a & STDa & 2.4494 & 0.3265 & $0.4898 a$ & $0.8164 a$ & 1.63290 \\
\hline W04a & Average $x$ & $733 x$ & 6.10 & $6.7 \%$ & $30 x$ & $1222 \alpha$ \\
\hline a & STD & 0.7266 & 0.2449 & 0.57150 & $0.4082 \mathrm{x}$ & 8.16490 \\
\hline W05a & Averagex & 2240 & 6.10 & $4.7 \times$ & $28 x$ & 3730 \\
\hline$a$ & STDa & 3.26590 & 0.0816 & $0.5715 x$ & $0.08164 x$ & 4.89890 \\
\hline W06a & Averagex & $425 x$ & 6.80 & 7.20 & 280 & $650.5 x$ \\
\hline a & STDa & $0.9797: 0$ & 0.1632 & $0.0816 x$ & $0.4082 x$ & $4.4907 ø$ \\
\hline W07a & Average $x$ & 2780 & 6.80 & 6.80 & $28 x$ & $430 x$ \\
\hline$a$ & STD $a$ & 0.8164 & 0.65310 & 0.16320 & $0.2449 x$ & 4.08240 \\
\hline W08 $a$ & Average $x$ & $460 x$ & 6.90 & 6.90 & $25 x$ & $700 x$ \\
\hline$a$ & STD $a$ & 0.89810 & 0.0816 & 0.32650 & $4.082 x$ & $16.3299 x$ \\
\hline W09a & Average $x$ & $160 x$ & $6.7 \mathrm{a}$ & $6.7 x$ & 280 & 250 \\
\hline$a$ & STD $a$ & 0.48980 & 0.4082 & 0.0816 & $0.2449 a$ & 1.63290 \\
\hline W10a & Average $x$ & 8870 & 6.90 & $* * * 0$ & $30: 0$ & 14790 \\
\hline$a$ & STDa & 0.0816 & 0.57150 & $* * *: a$ & $0.4898 \alpha$ & $7.3484 a$ \\
\hline & LSSa & $1000 x$ & $6.5-8.60$ & $-a$ & $\alpha$ & $2000 x$ \\
\hline & WHOr & 10000 & $6.5-8.50$ & 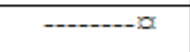 & $-1+2$ & 20000 \\
\hline
\end{tabular}

STD: Standard deviation; DO : Dissolved oxygen

The temperature of the groundwater in the studied wells has values ranging between 28 to $30^{\circ} \mathrm{C}$. Cool waters are generally more potable for drinking purposes, hot water enhances the growth of microorganisms and 
hence, taste, odour, color and corrosion problem may increase (Okoye and Okoye, 2008)

Metal corrosion problem are also associated with high temperature especially when the $\mathrm{pH}$ of the water reflecting more acidic. It was observed from the $\mathrm{pH}$ value that water samples changing from 5.9 to 6.9 and these values are within the limits prescribed by World Health Organization (WHO) (pH within 6.5-8.5) According to European economic community report (Indirabai and George, 2002), the permissible standard for drinking water for dissolved oxygen (DO) is 5 ppm and above, and Renn, C.E. postulated 6 ppm and above as the standard desirable limit of oxygen for water, but this value varies depending upon water temperature and the partial pressure of oxygen in its gas phase. (Renn, 1970)

The DO of groundwater in the studied wells has the value above $6 \mathrm{mg} / \mathrm{L}$ Except for one well (5). Conductivity is a measure of the ability of a fluid to carry an electrical charge, this ability is directly related to the concentration of dissolved substance, where the greater the total dissolved substances in water, the greater the conductivity of the water.

The electrical conductivity (EC) for all samples fell above the permissible limit of $2000 \mu \mathrm{S} / \mathrm{cm}$ set by WHO. EC is an indicator of water quality and soil salinity. Hence the relatively high values observed in some water samples showed high salinity such as wells No. $(10,4)$. The electrical conductivity (EC) has the value $1222,1479 \mu \mathrm{S} / \mathrm{cm}$ respectively; this reflects very suitable water for domestic and agricultural use (Goel, 2000). 
Total Dissolved Solids (TDS) is a measure of the dissolved combined content of all inorganic and organic substances contained in a liquid in: molecular, ionized or micro-granular. The principal application of TDS is in the study of water quality, although TDS is not generally considered a primary pollutant, it is used as an indication of a esthetic characteristics of drinking water and as an aggregate indicator of the presence of a broad array of chemical contaminants. The groundwater is classified as fresh water (TDS $<2.5 \mathrm{~g} / \mathrm{L})$, slight saline water $(2.5 \mathrm{~g} / \mathrm{L}<\mathrm{TDS}<5 \mathrm{~g} / \mathrm{L})$ and saline water (TDS $>5 \mathrm{~g} / \mathrm{L}$ ) in the standard of groundwater of Libya (Hamad, 2012). The TDS of wells (1-2-3-5-6-7-8-9) ranges between 160 to $460 \mathrm{mg} / \mathrm{L}$, indicating fresh water, while it increases in the wells Nos. (4 and 10) and changes from $(2.9 \mathrm{~g} / \mathrm{L})$ to $(4.1 \mathrm{~g} / \mathrm{L})$.

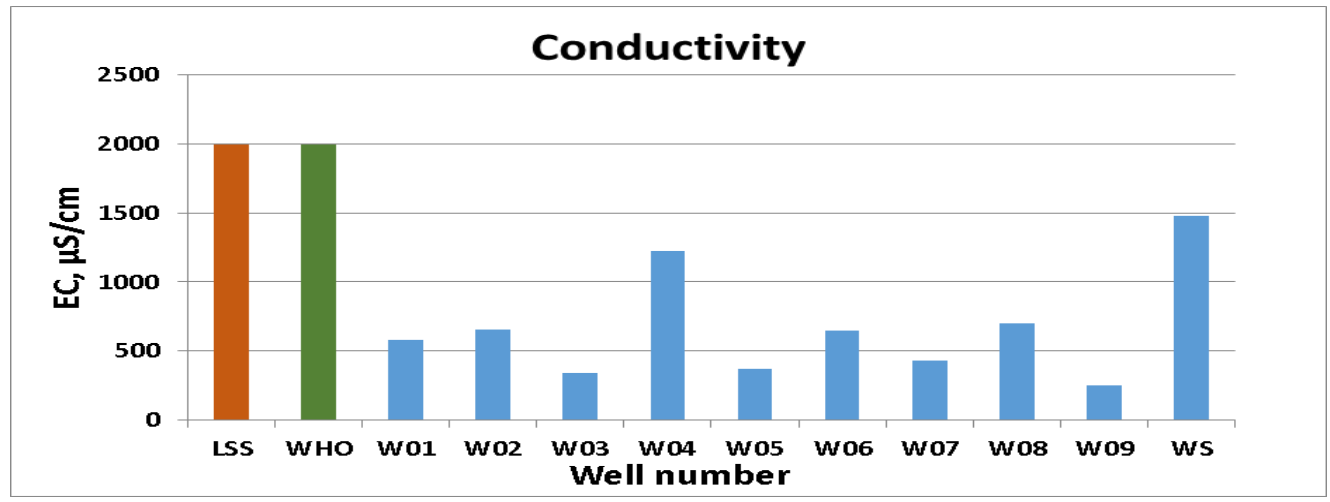

Fig. (12): Conductivity $(\mu \mathrm{S} / \mathrm{cm})$ of the studied wells compared with Libyan Standard and WHO. 


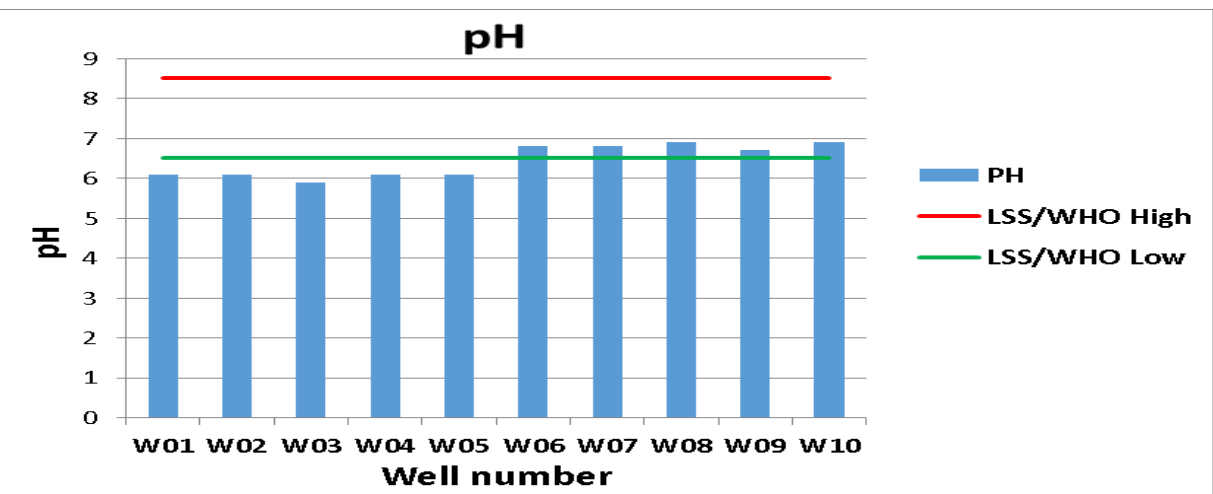

Fig. (13): pH of the studied wells compared with Libyan Standard and WHO.

The Piper tiliner diagram, which represents one of the most useful data representations in determining the quality of groundwater (Fig.14), was adopted. This diagram is made up of two lower triangles showing the percentage distribution, based on the equivalent of $\mathrm{MCI}$, for the main cations $(\mathrm{Mg}++, \mathrm{Ca}++, \mathrm{Na}+$ plus $\mathrm{K}+)$ and the main anions. A part of the shape above the shape summarizes the cations and anions to refer to the final water layer Cation distribution indicates that samples in wells $(3,4,10,1,2)$ contain a mixed combination of calcium and sodium.

Samples of wells $(8,5,6,7)$ have a calcium composition. While the formation of wells (4 and 10) is sodium. In the anion triangle, there is a type of demand for bicarbonate water for the sample (well 4, 1.7) and water chloride type for the samples (well 4-10).

All samples lie at the top of the diamond shape which proves the initial salinity character. This reflects access to a high salt source either by surface water leakage or by the reaction and evaporation of salts within the water rocks, as well as by the increase in the amount of groundwater withdrawals. 


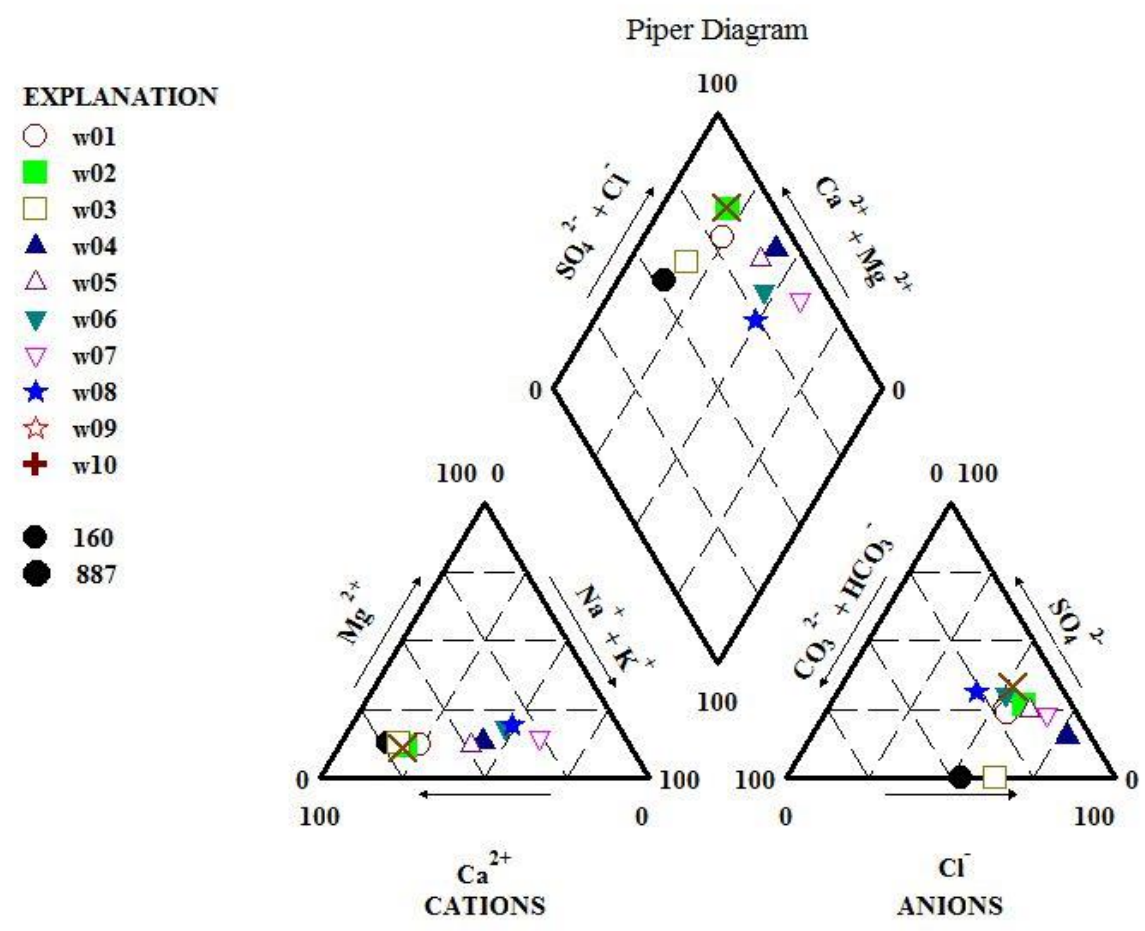

Fig(14): Piper diagram of groundwater samples of the studied wells

Microbiological Analysis: The total count of bacteria per $\mathrm{ml}$ of sample for to well were ranged from 1 to $4 \mathrm{CFU} / \mathrm{ml}$ for well numbers $(2,3,4,5 \& 10)$. On the other no growth count of bacterial colony for the well numbers $(1,8,9,7$ \& 6) respectively (Table 5).

The total count of coliform per $100 \mathrm{ml}$ isolated from 10 well samples were ranged from 1 to $4 \mathrm{CFU} / \mathrm{ml}$ which suggest faecal contamination of groundwater with coliform bacteria. None of other wells were recorded any coliform number (Table 5). 
Table(5): Microbiological analysis of Al-Kufra groundwater

\begin{tabular}{||c|c|c||}
\hline Well No. & Unit & Result \\
\hline \hline W01 & Colony $/ 100 \mathrm{ml}$ & NO Growth \\
\hline W02 & Colony $/ 100 \mathrm{ml}$ & 4 \\
\hline W03 & Colony $/ 100 \mathrm{ml}$ & 2 \\
\hline W04 & Colony $/ 100 \mathrm{ml}$ & NO Growth \\
\hline W05 & Colony $/ 100 \mathrm{ml}$ & NO Growth \\
\hline W06 & Colony $/ 100 \mathrm{ml}$ & NO Growth \\
\hline W07 & Colony $/ 100 \mathrm{ml}$ & NO Growth \\
\hline W08 & Colony $/ 100 \mathrm{ml}$ & 2 \\
\hline W09 & Colony $/ 100 \mathrm{ml} ~$ \\
\hline W10 & Colony $/ 100 \mathrm{ml}$ & \multicolumn{2}{c}{} \\
\hline
\end{tabular}

\section{CONCLUSIONS}

To demonstrate the utilization of groundwater in the study area and to know the areas of their use and ensure safety. The results of the present investigation were evaluated and compared with the Libyan standards and the international standards (WHO, 2011). Since water quality determines its suitability for different uses, the Al-Kufra area needs water for drinking and irrigation purposes, it is necessary to discuss the groundwater valuation specifically. Based on the chemical analysis data carried out during this study and in accordance with (WHO) standards, the groundwater of wells $(4,10$, inclusive) appears to have higher values than the Libyan standards and (WHO) standards and cannot be used for drinking purposes. The wells suffer $(2,3,4,5$ and 10) of groundwater contamination with coliform bacteria, because the number of colonic bacteria compared to the acceptable value, while the other wells recorded no presence of coliform, in particular 
pollutants originating in wastewater, especially in the wells near the drainage sites. The present study recommended the routine monitoring the groundwater quality every fixed period before consumption. Also, the need to accelerate the establishment of sanitation system to save the groundwater supplies in the region.

\section{REFERENCES}

Abufayed, A.A. and Elkebir, A.A. (2010) Water supply and sanitation in Libya: Gap analysis, national needs and UNDP interventions strategic entry points identification. Water Governance Program for Arab States, Tripoli, 1, 1-55

APHA (1998) Standard Methods For The Examination Of Water And Waste Water, 19th ed (American Public Health Association, Washington, DC, 2-179.

Goel, P.K. (2000): Water Pollution - Causes, Effects and Control, New age Int. (P) Ltd., New Delhi.

Hamad, M.S. (2012): Status of Groundwater Resource of Al Jabal Al Akhdar Region, North East Libya International conference of the Water Resources and Water Security in the Middle East and Mediterranean Region .Amman Jordan(http://ar.ewdr.org/).

Hosan S. K.; Usmani, F.; Zaiad, G. M. and Edra, S. (2011) Physicochemical analysis of municipal water in Al-Khums city, Libya, Water Research \& Development, 2011, 1, 56-58.

Hydrology of Groundwater/Author of Khalifa Daradka Dar Al Bashir, Amman 1988

Indirabai, W.P.S. \& George.S. (2002): Assessment of drinking water quality in selected areas of Tiruchirappalli town after floods. Poll. Res., 21(3), 243-248 .

Jha, A.N. and Verma P.K. (2000): Physico-chemical properties of drinking water in town area of Godda district under SantalPargana (Bihar), India, Poll. Res., 19(2), 75-85 .

LNCSS, (1992): Libyan National Center for specifications and standards, Drinking water standards. No. 82. 
Noble, R.T.; Leecaster, M. K.; McGee, C. D.; Weisberg, S.B. and Ritter, K. (2003): "Comparison of Total Feacal Coliform and Enterococcus Response for Ocean Recreational Water Quality Testing," Water Research, 37, No. 7, pp. 1637-1643.

Okoye, C.O., and Okoye, A. C., (2008) Urban Domestic Solid Waste Management. Nimo: Rex Charles and Patrick Limited Awka, pp.5-7

Renn, C.E. (1970): Investigating water problems. Educational products division, La Molte chemical products company, Maryland.

Salem, M.A.; Alshergawi, M.I. (2013) Physico-chemical Evaluation of Drinking Water Quality in Alshati District of Libya, IOSRJournal of Environmental Science, Toxicology and Food technology, 4, 46-51.

Shahin, M. (2003) Hydrology and Water Resources of Africa, Groundwater Resources of Africa; Kluwer Academic Publishers: New York, NY, USA, p. 529.

WHO, (1993): Guidelines for drinking water quality. (2nd ed.)1 Recommendations, Geneva, ISBN 924154460 .

WHO (1996): Guidelines for drinking-water quality, Health criteria and other supporting information. World Health Organization, Geneva, 2nd ed. Vol. 2.

WHO (World Health Organization) (2011): Guidelines for drinking-water quality - 4th Edn, Gutenberg, 541p...

Wright, J.; Gundry, S. and Conry, R. (2004): Household drinking water in developing countries: a systematic review of microbiological contamination between source and point-of-use. Tropical Medicine and International Health, 9(1), 106-117. 


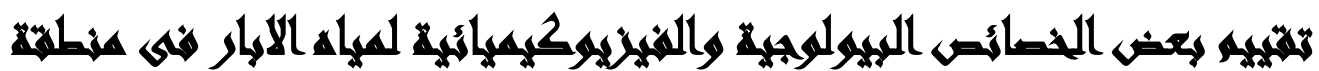

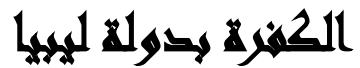

\section{[1]}

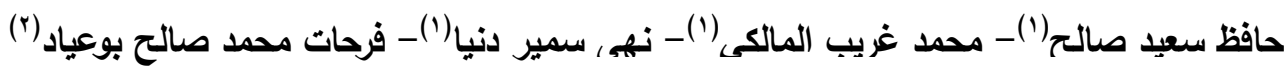

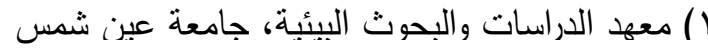

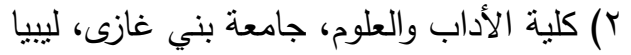

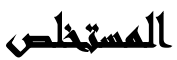

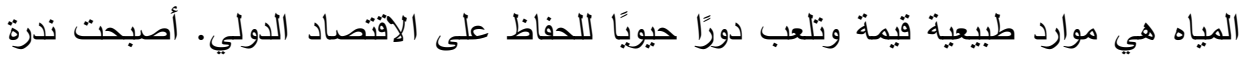

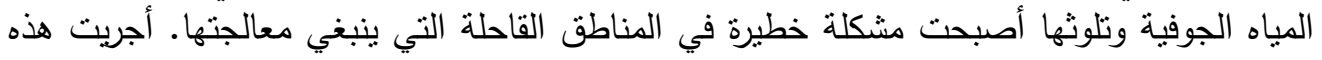

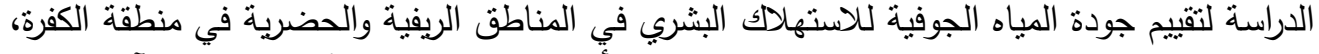

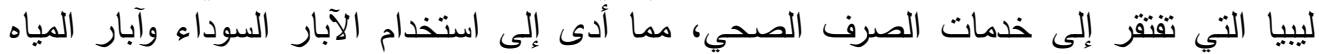

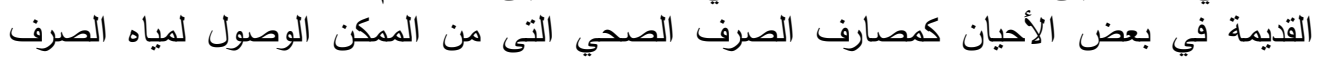

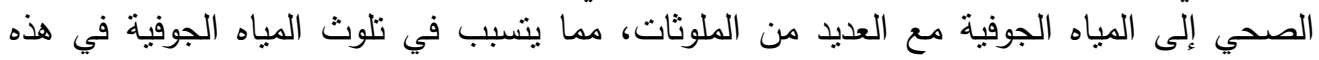

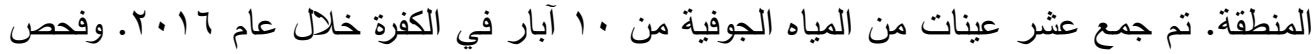
الخصائص الفيزيائية مثل الرقم الهيدروجيني، الموصلية الكهربائية (EC) والمواد الصلبة الذية الذائبة الكلية

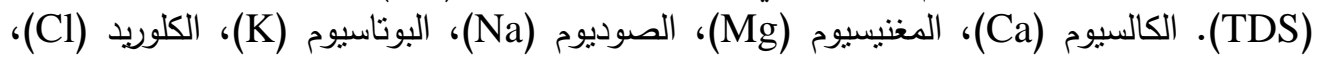

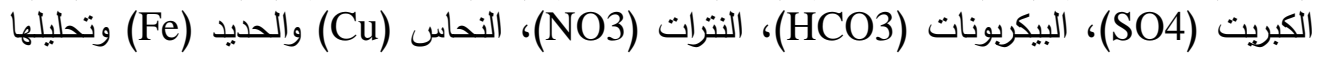

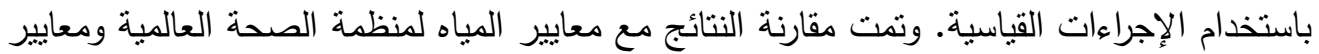

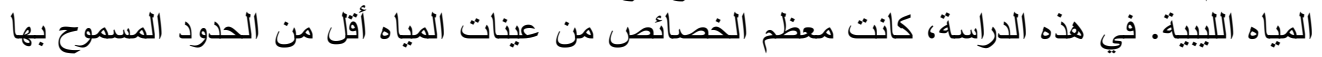

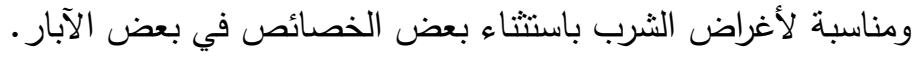

